\title{
Land use change and shifts in gender roles in central Sumatra, Indonesia
}

\author{
G.B. VILLAMOR ${ }^{1,2}$, R. AKIEFNAWATI², M. VAN NOORDWIJK², F. DESRIANTI ${ }^{3}$ and U. PRADHAN ${ }^{2}$ \\ ${ }^{1}$ Department of Ecology and Natural Resources Management, Center for Development Research (ZEF), University of Bonn, Germany \\ ${ }^{2}$ World Agroforestry Centre (ICRAF), Southeast Asia Regional Office, JL. CIFOR, Situ Gede, Bogor, Indonesia \\ ${ }^{3}$ Center for International Forestry Research (CIFOR), JL. CIFOR, Situ Gede, Bogor, Indonesia
}

Email: gracev@uni-bonn.de

\begin{abstract}
SUMMARY
While Indonesia is experiencing a rapid land use transition due to export-oriented growth in agricultural products such as palm oil and natural rubber, there is no clear understanding of how shifts in farming practices influence gender-specific roles and preferences. In a partially matrilineal society on Sumatra where rice production for subsistence purposes, in an agroforestry landscape, is traditionally considered the women's domain and responsibility, 202 households were surveyed about their perceptions of gender-specific agricultural roles. Over time, rice fields have been converted to oil palm. Lowland women have increasingly significant roles in rubber agroforestry in addition to collecting firewood, medicinal plants and wild fruit for household consumption, whereas men are typically occupied in monoculture oil palm or rubber production. As land use patterns rapidly change, particularly in the lowlands, the responsibility of rubber agroforestry systems is shifting from men to women with consequences for gender division of labour and decision making.
\end{abstract}

Keywords: elevation, gender equality, matrilineal kinship, rubber agroforestry, transition intensity

\section{Changements dans l'utilisation de la terre et dans le rôle des sexes au coeur de Sumatra en Indonésie}

\section{G.B. VILLAMOR, R. AKIEFNAWATI, M. VAN NOORDWIJK, F. DESRIANTI et U. PRADHAN}

Alors que l'Indonésie connaît une transition rapide dans l'utilisation de ses terres, due à une croissance tournée vers l'exportation dans ses produits agricoles tels que l'huile de palme et le caoutchouc naturel, il n'existe pas de claire vision sur la manière dont les changements de pratiques fermières influencent les rôles et les préférences spécifiques aux sexes. Dans une société partiellement héritée par la ligne féminine à Sumatra, où la production de riz pour la subsistance, dans un paysage agroforestier, est traditionnellement considérée comme le domaine et la responsabilité des femmes, 202 foyers ont été étudiés quant à leur perception des rôles spécifiques attribués aux sexes dans l'agriculture. Au cours du temps, les rizières ont été converties en plantations productrices d'huile de palme. Les femmes des terres basses ont un rôle de plus en plus conséquent dans l'agroforesterie du caoutchouc, qui s'ajoute au ramassage du bois, des plantes médicinales et des baies sauvages pour la consommation des foyers; alors que les hommes s'occupent typiquement de la monoculture de l'huile de palme ou de la production de caoutchouc. Alors que les habitudes d'utilisation de la terre se modifient, dans les terres basses tout particulièrement, la responsabilité des systèmes d'agroforesterie du caoutchouc passe des hommes aux femmes, avec des conséquences quant à la division du labeur entre les sexes, et quant aux prises de décisions.

\section{Cambios en el uso del suelo y en los roles de género en Sumatra central (Indonesia)}

\section{G.B. VILLAMOR, R. AKIEFNAWATI, M. VAN NOORDWIJK, F. DESRIANTI y U. PRADHAN}

Aunque Indonesia está experimentando una rápida transición en el uso del suelo debido al crecimiento orientado a la exportación de productos agrícolas como el aceite de palma y el caucho natural, no está claro cómo influyen los cambios en las prácticas agrícolas en las funciones y preferencias específicas de género. En una sociedad parcialmente matrilineal como la de Sumatra, donde la producción de arroz para fines de subsistencia dentro de un paisaje agroforestal se considera tradicionalmente el dominio y la responsabilidad de las mujeres, se encuestaron 202 hogares con relación a sus percepciones acerca de los roles agrícolas en función del género. Con el paso del tiempo, los campos de arroz se han convertido en cultivos de palma de aceite. Las mujeres de las tierras bajas tienen papeles cada vez más importantes en la agroforestería del caucho, además de la recolección de leña, plantas medicinales y frutos silvestres para el consumo del hogar, mientras que los hombres suelen ocuparse de la producción de monocultivos de palma aceitera o de caucho. A medida que los patrones de uso del suelo cambian rápidamente, sobre todo en las tierras bajas, la responsabilidad de los sistemas agroforestales de caucho está pasando de los hombres a las mujeres, con consecuencias para la división del trabajo con base en el género y la toma de decisiones. 


\section{INTRODUCTION}

Land use patterns on the island of Sumatra, Indonesia, are changing rapidly with direct contributions to economic growth as well as environmental change. These changes have been interpreted as destruction, degradation or improvement depending on the point of view of those who lose or gain from the transition. Consequences of these land use transitions on gender differences in roles and perspectives have not been studied in detail. Elsewhere changes in gender-specific roles have been investigated in relation to changing agricultural practices due to the growth of export-oriented agricultural products such as palm oil and natural rubber (Rudel et al. 2009, DeFries et al. 2010, Villamor et al. 2014a). Globally, Indonesia is ranked first in the production of oil palm (Elaeis guineensis) and second for natural rubber (Hevea brasiliensis), with a large-scale agroindustry and smallholder actors active in both crops; most of the production comes from Sumatra. Broadly speaking, gender-differentiated roles fall into three main categories (Peter 2006): 1) reproductive tasks such as child bearing and rearing, feeding the family, and caring for the sick; 2) productive work that either produces goods or services for household consumption or for sale in the market for cash or in kind; and 3) social/community activities performed not only for family welfare, but also for public well-being and community related responsibilities. Of the three main categories of gender-differentiated roles, this research concentrated mainly on the productive roles between smallholder men and women where the landscape is undergoing rapid land use transitions. There is a significant amount of literature featuring inequality in the burdens associated with the traditional roles of women as compared to men (Peter 2006), which may lead to household inefficiency and functional decline, as well as health problems (e.g., nutrient deficiencies) (Udry et al. 1995, Adesina and Djato 1997, Harris 2014). This research examined the shifting genderspecific agricultural roles of men and women in a traditional, partially matrilineal society experiencing a relatively gradual transition to more intensive tree crop production. Adjacent to the matrilineal society in West Sumatra, social patterns in the province of $\mathrm{Jambi}^{1}$ have led to matrilineal patterns for rice production and mixed male-preferential inheritance for tree crop land (see below).

Gender equality and equity are now understood to be central to environmental sustainability and are therefore among the high-priority goals to be addressed in the Post2015 Sustainable Development Agenda (Meinzen-Dick et al. 2014). Perceptions and practice of equality and equity are important for better social and gender relations, reduction of discontent and conflicts that, to a certain extent, do not provide an enabling environment for use and management of natural resources. Though many studies have linked gender issues to agriculture, land tenure, labour equity and food security (Meinzen-Dick et al. 1997, Quisumbing et al. 2001,
Meinzen-Dick et al. 2012), very few have investigated how gender-specific roles are being affected by the changing land use, which in turn also has implications for environmental sustainability (Colfer and Minarchek 2013, Bernard et al. 2014, Villamor et al. 2015). Another aspect that merits attention is the link between the two phenomena in that gender differences may shape the functionality of landscapes that provide crucial ecosystem services in the face of various uncertainties (e.g., climate change)(Villamor et al. 2014b). One particular aspect that needs further emphasis is the relationship between gender and land use decisions (i.e., preferences regarding new land use and vegetative cover options) over temporal and spatial dimensions that may affect the land's capacity to provide different goods and ecosystem services. This includes gender based dissimilarities in lifestyles and consumption patterns that affect environmental conditions. Such changes need to be understood in a social historical perspective of the local context.

The customary gender division of labour within traditional farming systems in Jambi, a part of central Sumatra and adjacent to the fully traditional matrilineal West Sumatra is described in the next section. This is followed by an assessment of the trends in land use changes that occurred between 1988 and 2010 to determine the major shifts in agricultural activities in the study area. The section on results presents the perspectives of men and women regarding their productive roles in agriculture and provides answers to the following research questions:

1) Do men and women agree on who performs specific productive roles?

2) Do men and women have similar perceptions regarding productive roles across an elevation gradient?

It was assumed that gender-specific roles are also changing due to land use transitions in the study area and terrain features, associated with elevation, are one of the determinants of land use change. Furthermore, the land inheritance systems were explored according to the elevation gradient, which was expected to provide more insight into gender equity and equality.

\section{Customary gender-differentiated roles in central Sumatran agriculture and agroforestry models}

The Minangkabau, the indigenous communities of West Sumatra Province, continue to observe traditional customs, which include a clear division of labour and roles between men and women with respect to farming activities (e.g., land preparation, planting, harvesting). The Minangkabau ethnic group remains the largest surviving matrilineal society in the world (Kato 1978, Blackwood 1999). In this society, marriage is matrilocal/matriarchal and women landholders dominate

\footnotetext{
1 We used the geographical term 'central Sumatra' here for a combination of the provinces of West Sumatra, Jambi and Riau (this refers to the area South and North of the equator).
} 
the landscape as effective heads of households, which are built around matrilineal ties and actively farm their own lands with the help of husbands (Blackwood 2008). According to their local customs women are responsible for managing rice fields, while the men are responsible for clearing land, fencing, harvesting and post-harvest activities. Ancestral land, which includes rice lands and house land, is traditionally owned by clans and typically inherited matrilineally (Colfer $e t$ al. 1988, Suyanto et al. 2001, Blackwood 2008, Villamor et al. 2014c). In adjacent areas of central Sumatra (around the equator) communal and matrilineal ownership dominates rice production, but the management of rubber production areas is much more individualized and is performed by planting rubber trees to mark land where single-family ownership is bequeathed to a son (Suyanto et al. 2001, van Noordwijk et al. 2012). Men's land rights appear to increase when they cultivate rubber trees, while within-village marriages allow these separate inheritance rules for rice fields and other land to coexist. Under the customary division of labour in this area, tapping (harvesting) rubber trees is mainly men's work, thus men predominate in most rubber production activities. Quisumbing and Otsuka (2001) described the evolution of the land tenure system among the Minangkabau ethnic group and adjacent areas that led to increased efficiency and equity. However, gender relations go beyond the nuanced labour divisions. Not all households are landowners and shared tenancy arrangements between landowners and tenants, in rubber production areas, exist that provide access to rubber production. Such shared-tapping contracts are typically arranged so that the tenant gives one-third of the harvest to the landowner and retains two-thirds (Colfer et al. 1988, Suyanto et al. 2001). Details of the shared-tapping arrangements vary between cyclical and internal-rejuvenation (or 'permanent') rubber agroforestry systems (Wibawa et al. 2005).

\section{Traditional agricultural systems and gender-specific roles in the study region}

Rubber and rice production have dominated agriculture in central Sumatra over the past century. Colfer et al. (1988) described these agricultural systems, in a study area in West Sumatra, but outside the core Minangkabau domain, as indigenous. This was because they do not follow the supposedly modern farming model in terms of fixed monoculture plots of specified size that are intensively cultivated. Instead, the indigenous agricultural systems are more fluid and influenced by site-specific factors such as topography and water availability, the type of agricultural system, and the stage of forest regeneration. Figure 1 presents the main traditional farming systems and gender roles in central Sumatra. Upland rice cultivation refers to production in piedmont areas, whereas lowland rice production is primarily on the peneplain. The indigenous farming systems in the area are also determined by the stage of forest regeneration and thus are more complex than the diagram represented in Figure 1. During the upland rice growing season fruit trees (e.g., jackfruit [Artocarpus heterophyllus], rambutan [Nephelium lappaceum] and stink
FIGURE 1 Simplified representation of traditional/indigenous agricultural practices in central Sumatra according to land use based on Colfer et al. (1988) for rice farming (a) and Wibawa et al. (2005) for rubber agroforestry (b)

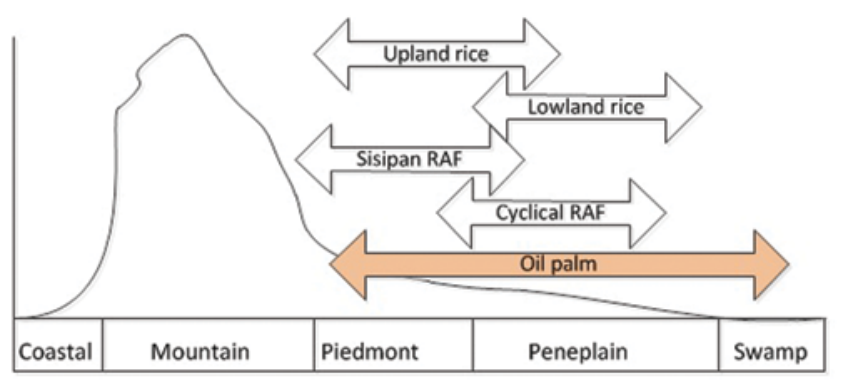

a) Rice farming (traditional)

\begin{tabular}{|c|c|c|c|}
\hline Gender & \multicolumn{3}{|c|}{ Activities/roles according to key stages } \\
\hline Females & clearing & weeding & harvesting \\
\hline Males & felling trees* planting frui & es & transport harvest \\
\hline
\end{tabular}

b) Rubber agroforestry (RAF)

\begin{tabular}{|c|c|c|}
\hline Gender & \multicolumn{2}{|c|}{ Activities/roles according to key stages } \\
\hline Females & clearing & tapping \\
\hline Males & tree removal & tapping \\
\hline
\end{tabular}

*Note: tree removal at the start of an upland rice cultivation cycle may spare some high-value trees; land is completely cleared for oil palm cultivation, which is considered a new farming system in the study area.

beans [Parkia speciosa]) are also planted. These tree crops are not sold in markets, but rather are consumed for subsistence purposes, which involve tasks that are primarily performed by females. Women in the Minangkabau women work in all phases of rice production (Blackwood 2008), whereas men are traditionally responsible for land preparation (especially in the lowlands) and for the transport of harvested rice from the field to the home. The decision of whether to replant rice (annually) is based on the previous rice harvest.

Most of the rubber agroforestry systems in Indonesia were established by clearing land, although anecdotes do refer to rubber seeding into existing fallow vegetation in the early phases of rubber expansion in the beginning of the 20th century (van Noordwijk et al. 1998). There are two types of rubber production systems based on the method of rubber tree regeneration (Wibawa et al. 2005). The first category is the cyclical rubber agroforestry system, where new cycles begin with repeated site clearing. Cleared land is subsequently planted with seedlings or grafted clones of rubber trees, typically by males, while women simultaneously plant a combination of rice and maize, which is more typical in the lowland peneplains (Figure 1). The second type of rubber production is locally called sisipan. According to Wibawa et al. (2005) sisipan is a permanent system where rubber trees regenerate from self-seeding or the planting of seedlings in forest gaps, mainly in the peneplains or foothills of mountains. Rubber agroforestry systems usually occupy small plots (e.g., 1 ha) 
that contain rubber trees of all ages and are common on Sumatra. The decision to plant or graft seedlings in forest gaps is based on the particular tree and not the plot. Agrochemical applications are uncommon within these traditional rubber agroforestry systems. In the early stages it is mainly the women who do the weeding, and in some cases women participate also in rubber tapping and the sale of rubber slabs.

\section{Roads, migrants and social change}

The 1970's brought a dramatic change in the land use patterns, economy and social landscape when road access replaced rivers (van Noordwijk et al. 2012). Transmigration sites, developed jointly with the road, resulted in spontaneous migration to all areas of the landscape. Miyamoto (2006) described how increased labour availability accelerated forest conversion, particularly in the lowlands. With the roads, the expansion of monoculture rubber became possible and profitable. The rubber could be transported from each village to the city market by mainly paved roads instead of by river. Complex patterns of interactions arose between local communities, migrants, private sector, national and local government (Galudra et al. 2014), with consequences for gendered role articulation in both migrants and local communities as analysed for southern Sumatra by Elmhirst (1999). In areas away from the city markets, with poor access roads especially in the uplands, farming practices remained traditional and few migrants moved in. Where accessible, the lowland forests of Sumatra have been converted to more intensified agriculture such as monoculture rubber and oil palm as attested by many studies (Laumonier et al. 2010, Broich et al. 2011, Margono et al. 2012).

\section{Non-traditional agricultural systems}

The traditional matrilineal inheritance system has undergone a substantial transformation in recent years (Otsuka et al. 2001, Quisumbing and Otsuka 2001). This transformation is associated with a shift in agricultural practices related to the conversion of rice fields (mainly upland) and rubber agroforest plots to monoculture rubber and oil palm plantations, mainly in the lowlands (particularly in the peneplain), due to several factors (Villamor et al. 2014c).

The intensification of rubber (hereafter 'monoculture rubber') and particularly oil palm plantations were brought to Sumatra in the late 1980s through the transmigration programme based on the Nucleus Estate System (NES) (Rist et al. 2010). Marjani and Irawati (1997) first described the system as a response to Presidential Decree No. 1 (1986) that intended to harmonize the agricultural interests of large private agro-industrial companies and smallholder farmers. Within NES each household was typically provided with two hectares (plasma plots) of land for oil palm and rubber production, and one hectare for residential and food production purposes that form a plantation nucleus. Under NES smallholders were provided technical support for planting as well as the transfer of parcel ownership to smallholders after 3-5 years when the oil palm harvesting begins. Individual farmers were able to pay the associated land costs in approximately 10 years with palm oil revenues. Due to this programme oil palm has rapidly become a smallholder dominated crop in Sumatra. Although, there is an abundance of literature on issues surrounding smallholder cultivation of oil palm (Jelsma et al. 2009, Feintrenie et al. 2010, Rist et al. 2010), to the best of our knowledge there have not been any published studies of gender based division of labour related to this transition in land use. One exception is a Hibun Dayak community in West Kalimantan, Borneo, where the women were found to spend more time (than they used to) cultivating oil palm plantations (Julia and White 2012).

\section{METHODS}

\section{Study area}

This study was conducted in the 114,414 ha of Bungo District, in Jambi Province, (central) Sumatra, Indonesia. The island of Sumatra is a global centre of deforestation due to the rampant expansion of oil palm and monoculture rubber production (Margono et al. 2012, Lee et al. 2014). In Bungo more than $30 \%$ of the remaining forest and rubber agroforest areas have been converted to monoculture oil palm and rubber plantations over the last 20 years (Ekadinata and Vincent 2011, Villamor et al. 2014a). Despite the high rate of agricultural land conversion, rubber agroforestry is still practiced in many of the villages in Bungo and forestry management is held in high regard (Akiefnawati et al. 2010).

The study was conducted in 15 villages in the two sub-districts of Bathin III Ulu and Pelepat Ilir where rubber agroforestry continues to be practiced despite the prevailing trend in land conversion (Figure 2). Bathin III Ulu is mainly at upland elevations, while Pelepat Ilir is in the lowlands. Some of the villages in Bathin III Ulu are located on the edge of a protected forest and Kerinci Seblat National Park where more complex rubber agroforestry systems are found along with upland rice cultivation. The topography of the upland villages is rather hilly and rubber agroforestry systems prevail between the main river and its tributaries. The villages in Pelepat Ilir have more typical (simple) rubber agroforestry systems. Villagers in this sub-district are considered the pioneers of monoculture rubber and oil palm plantations in the area. The topography of these lowland villages is typically flat where the plantations can be easily reached by motor vehicles. The villages in Pelepat Ilir have more access to roads and the rubber and palm oil markets.

\section{Data collection and analysis}

Land cover change assessment and intensity analysis

Land use maps of the study area from 1988, 1999, and 2010 were used to characterise local land use transition. The maps were processed from Landsat TM and Landsat ETM images that were validated by the World Agroforestry Centre (ICRAF) for the Landscape Mosaic project (Ekadinata and Vincent 
FIGURE 2 Study area in the Bungo District of Jambi Province, Sumatra, Indonesia

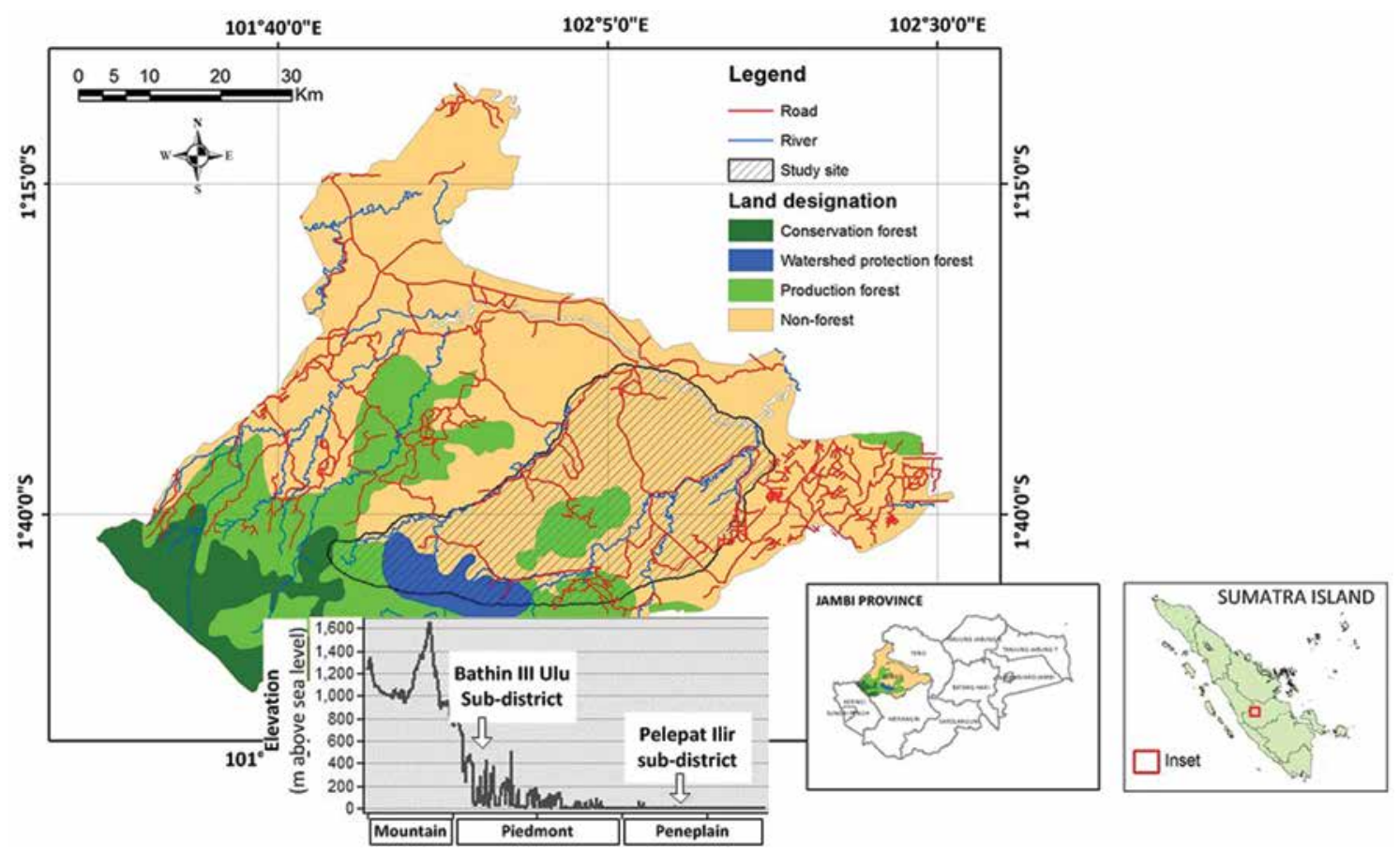

2011). All maps have a $30 \mathrm{~m} \times 30 \mathrm{~m}$ resolution. The maps were overlaid and the main land use types were cross tabulated using ArcGIS 9 to determine the percentage of land area change for specific periods. The principal land uses were forest, monoculture rubber, oil palm, rice fields and rubber agroforest.

To further understand the land use transition in the study area, we applied the land use intensity analysis as a mathematical framework that compares a uniform intensity versus observed intensities of temporal changes among land categories (Aldwaik and Pontius 2012). Within this framework, we specifically used the transition level analysis to answer the question: which transitions are 'targeting' versus 'avoiding' during a given time interval; which is formally expressed in Appendix 1 (Villamor et al. 2014a) and is quantified by a free computer programme available at https://sites.google.com/ site/intensityanalysis. If a transition's observed intensity is greater than the corresponding uniform intensity, the category targets the particular transition. If a transition's observed intensityis less than the corresponding uniform intensity, then thecategory avoids that particular transition.

In this way, the results of the analysis provide insights into which land use category is targeting the loss of another land use category and provide the basis of the shifts in farming practices.

\section{Gender-specific productive roles analysis}

A total of 202 respondents (50\% men and 50\% women), were randomly selected in the two sub-districts. The survey was conducted between May and June 2013 (two weeks in each sub-district) to determine gender-specific roles in farming and associated marketing activities. The respondents were asked about various productive, reproductive, and community roles and tasks that were appropriate for the study area (Table 1) using the 'Harvard analytical framework', also referred to as the 'gender roles framework' (Razavi and Miller 1995, Mulyotami et al. 2013). This framework addresses the question of 'who does what' for all productive, reproductive, and community tasks. The survey data were analysed with a simple Fisher's exact test using STATA 13 statistical software to determine if there was any correlation between gender and agreement or disagreement (Fisher 1922, Agresti 1992). Any activities found to be significant indicate that there are clearly 'distinct' opinions between genders. The separation of the analyses by elevation was made on the premise that most of the land use transition occurred in the lowlands whereas the uplands have maintained/retained traditional agricultural practices. In this way two hypotheses were tested:

(H1) Men and women have similar opinions with regards to productive roles by gender across the elevation gradient.

(H2) Men and women have similar opinions about whether productive roles are performed jointly or separately/individually.

\section{RESULTS}

\section{Land use change assessment and transition intensity analysis}

The trend in land use/cover change in the study area is summarized in Figure 3 and Table 2. Over the time period 
TABLE 1 List of activities/tasks according to the three classes of gender roles

\begin{tabular}{|c|c|c|}
\hline I. Productive role & II. Reproductive role & III. Community role \\
\hline $\begin{array}{l}\text { Applying herbicides/pesticides } \\
\text { Buying farm inputs } \\
\text { Clearing land } \\
\text { Farm finances } \\
\text { Feeding livestock } \\
\text { Fertiliser application } \\
\text { Harvesting palm oil } \\
\text { Harvesting trees } \\
\text { Maintaining farm records } \\
\text { Planting crops } \\
\text { Planting trees } \\
\text { Producing tree seedlings } \\
\text { Pruning trees } \\
\text { Rubber tapping } \\
\text { Selling (non-rice) crops } \\
\text { Selling agroforestry products } \\
\text { Selling rice } \\
\text { Transporting crops } \\
\text { Watering/irrigation } \\
\text { Weeding }\end{array}$ & $\begin{array}{l}\text { Caring for children } \\
\text { Cleaning the home } \\
\text { Collecting fuel-wood } \\
\text { Fetching water } \\
\text { Household finances } \\
\text { Preparing meals } \\
\text { Washing clothes }\end{array}$ & $\begin{array}{l}\text { Attending community activities } \\
\text { Attending school meetings } \\
\text { Cleaning public spaces } \\
\text { Participating in meetings (e.g. new farm technology) } \\
\text { Village tree planting }\end{array}$ \\
\hline
\end{tabular}

encompassing the 1988, 1999 and 2010 satellite images the following trends were observed: (1) forest cover continuously and rapidly decreased (by 14\% between 1999 and 1988, and by $21 \%$ between 1999 and 2010), (2) rubber agroforest increased, but was becoming more highly fragmented, (3) monoculture rubber increased dramatically (by $18 \%$ between 1999 and 2010), and (4) oil palm, rice fields and settlement areas increased.

Based on the elevation gradient (see the cross-section of the study area in Figure 1), the results suggest that most of the land use changes have occurred in the lowland areas. Most lowland forests and rubber agroforests were converted to monoculture rubber (Figure 3). Conversion of rubber agroforest to monoculture is reversible. Oil palm production is less than $1 \%$ of the total study area; the farm area under oil palm plantation currently consists of small patches in a mosaic across the lowlands (Villamor et al. 2014a). The traditional rubber agroforests remain mostly in the uplands of the study area. Monoculture rubber is the dominant land use, especially in the lowlands. These findings are consistent with the recent results of a land use change study by Gatto et al. (2014).

Figure 4 presents the transitional level intensities of the two traditional agricultural practices or land use categories namely rice field and rubber agroforests during 1999-2010. It helps to understand which transitions are targeting versus avoiding during a given time interval. It shows that a rice field's gain (target) is a rubber agroforest's loss while an oil palm's gain (target) is mainly a rice field's loss (Figure 4a). On the other hand, the rubber agroforest's gain (target) is a monoculture rubber's loss while the gains of monoculture rubber, oil palm and rice field are mainly from rubber agroforest's loss (Figure 4b). However, since most of the apparent land use changes occurred in the lowland (Figure 3 ), the rice field and rubber agroforest losses happened mainly in the lowland and the following results from household surveys support this observation.

\section{Descriptive characteristics of respondents}

Table 3 presents the descriptive characteristics of the survey respondents in the study area. In the lowland, the mean farm size of oil palm is 0.6 ha, with almost none in the uplands. For monoculture rubber, the mean farm size $(0.5 \mathrm{ha})$ in the lowlands is more than twice the size of the mean farm size ( 0.2 ha $)$ in the uplands. The mean farm size $(0.5$ ha) of rice fields among the upland respondents is four times as large as those belonging to the lowland respondents $(0.1$ ha). Upland survey respondents reported rubber agroforestry systems with a mean farm size that is one hectare larger than the mean size of rubber agroforestry systems owned by lowland respondents. Moreover, the upland respondents reported a mean landholding area of 6.5 ha, while the mean area of landholdings is almost 5 ha for the lowland respondents; however, this might include other land uses such as logged forest or fallow and shrub areas (Table 2). These characteristics suggest that in terms of farming practices, upland respondents are more traditional while lowland respondents are mainly non-traditional.

\section{Gender-specific productive roles}

Who performs the specific productive roles in major agricultural systems?

The answers to this question are presented in Figure 5, which shows the distributional percentages of tasks performed by men and women in the study site. The results suggest that men 
FIGURE 3 Composition of key land use classes in the study area in 1988, 1999, and 2010

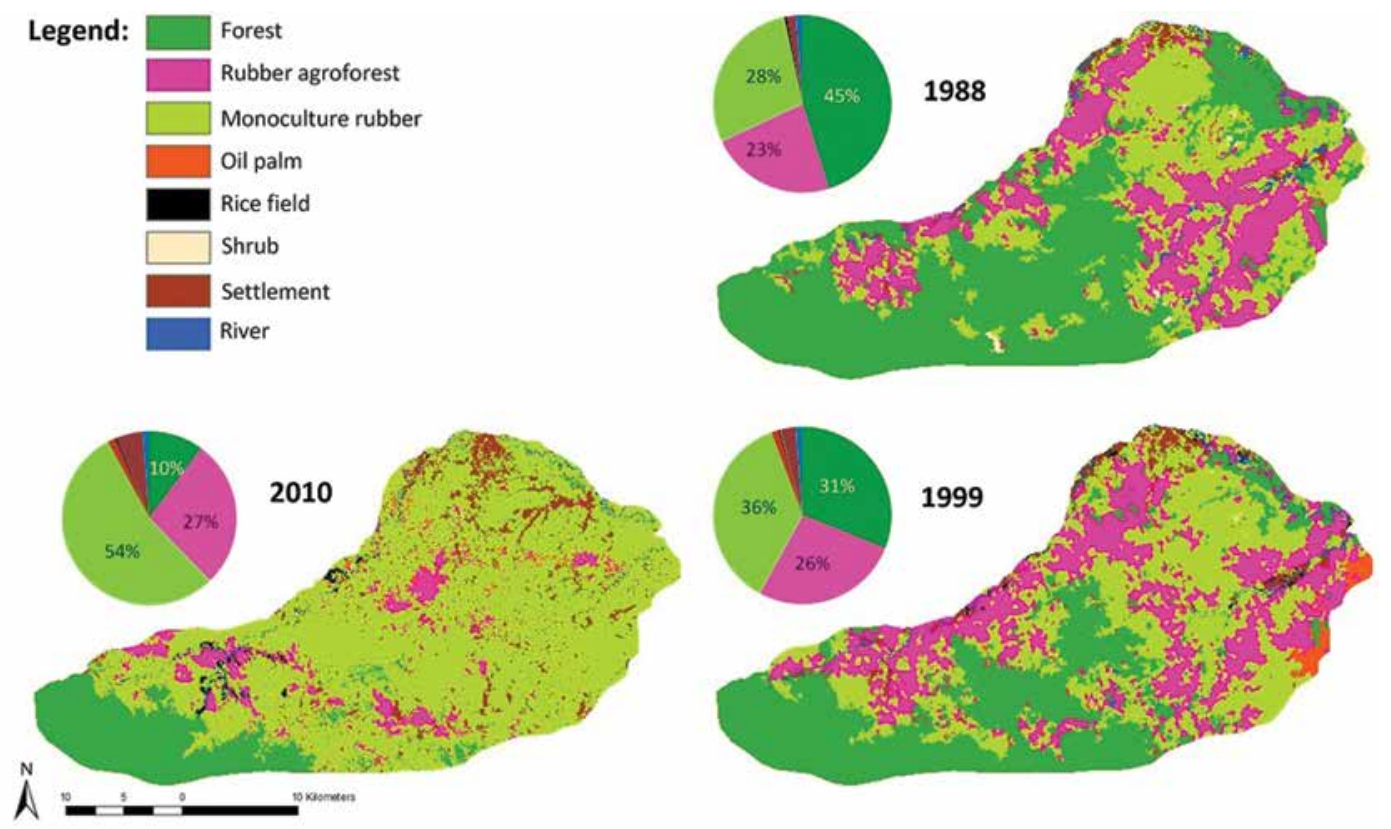

TABLE 2 Land use classes by area (ha) and change over two time intervals: (1) 1988-1999 and (2) 1999-2010

\begin{tabular}{|c|c|c|c|c|c|}
\hline \multirow{2}{*}{ Land-use type } & \multirow{2}{*}{1988 (ha) } & \multirow{2}{*}{1999 (ha) } & \multirow{2}{*}{2010 (ha) } & \multicolumn{2}{|c|}{ Land-use change } \\
\hline & & & & 1988-1999 (\%) & $1999-2010(\%)$ \\
\hline Forest & 51,755 & 35,576 & 11,653 & -14.1 & -20.9 \\
\hline Rubber agroforest & 26,061 & 30,757 & 31,571 & 4.1 & 0.7 \\
\hline Monoculture rubber & 32,574 & 41,520 & 62,082 & 7.8 & 18.0 \\
\hline Oil palm & 72 & 1,540 & 1,739 & 1.3 & 0.2 \\
\hline Rice field & 174 & 374 & 458 & 0.2 & 0.1 \\
\hline Shrub & 578 & 97 & 20 & -0.4 & -0.1 \\
\hline Settlement & 1,841 & 3,173 & 5,510 & 1.2 & 2.0 \\
\hline River & 1,360 & 1,378 & 1,381 & 0.0 & 0.0 \\
\hline Total & 114,415 & 114,415 & 114,415 & & \\
\hline
\end{tabular}

FIGURE 4 Transitional level intensities for rice field (a) and rubber agroforest $(b)$ during 1999-2010. Units are annual percent of the non-rice field ( $a$ ) and non-rubber agroforest ( $b$ ). If a bar extends beyond the uniform intensity line, then its category targets. If a bar stops short of the line, then its category avoids

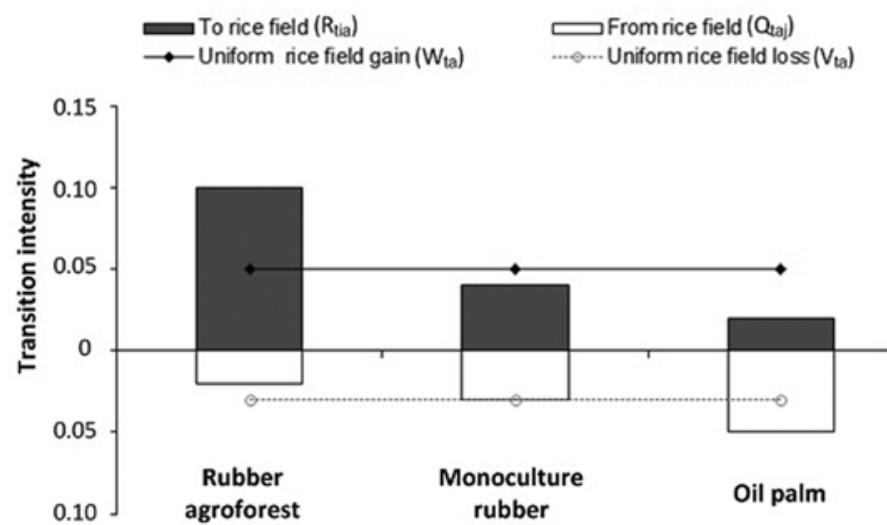

(a)

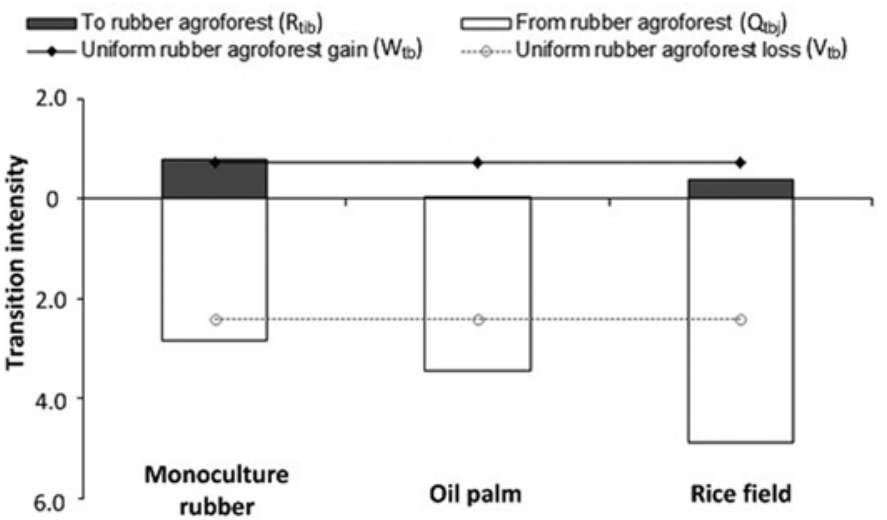

(b) 
TABLE 3 Descriptive statistics of the survey respondents in the study area $(N=202)$

\begin{tabular}{lllccc}
\hline Variable & Elevation & $\mathbf{n}$ & $\begin{array}{c}\text { Mean } \\
\overline{\mathbf{x}}\end{array}$ & $\boldsymbol{X}_{\text {Min }}$ & $\boldsymbol{X}_{\text {Max }}$ \\
\hline Age & Lowland & 100 & 45 & 23 & 82 \\
\cline { 2 - 6 } & Upland & 102 & 42 & 19 & 84 \\
\hline Labour availability (number of household \\
member >15 years old) & Lowland & 100 & 3.1 & 0 & 7 \\
\hline Oil palm (ha) & Upland & 102 & 3.0 & 1 & 8 \\
\hline Monoculture rubber (ha) & Lowland & 100 & 0.6 & 0 & 6.5 \\
\cline { 2 - 6 } & Upland & 102 & 0 & 0 & 0 \\
\hline Rice field (ha) & Lowland & 100 & 0.5 & 0 & 8 \\
\cline { 2 - 6 } & Upland & 102 & 0.2 & 0 & 3 \\
\hline Rubber agroforest (ha) & Lowland & 100 & 0.1 & 0 & 1.0 \\
\cline { 2 - 6 } & Upland & 102 & 0.5 & 0 & 3.5 \\
\hline Total landholdings (ha) & Lowland & 100 & 3.5 & 0 & 26 \\
\cline { 2 - 6 } & Upland & 102 & 4.5 & 0 & 58 \\
\hline
\end{tabular}

are mainly responsible for more physically demanding activities such as clearing land (i.e. in preparation for planting rice), harvesting tree-based products (rubber) and other crops (oil palm), transporting harvests, planting and applying agrochemicals. Women on the other hand play a greater role in controlling the farm finances and do less physical work (Figure 5b). However, some gender specific productive roles vary according to elevation. For example, in the lowlands, among the productive roles that differed in perspective between men and women are planting trees, feeding livestock, fertiliser application, watering/irrigation, rubber tapping, harvesting oil palm fruit, selling agroforestry products, selling rice and farm finances (Figure 5). In terms of other gender specific roles, almost $100 \%$ of women confirmed that they are responsible for the reproductive roles and $100 \%$ of the men confirmed that they are responsible for the social/ community roles.

Do men and women perceive the same productive roles across elevations?

According to the men's perspectives, they are mainly responsible for various farming activities. On the other hand, women's perspectives were consistent with the perceived roles of men as shown by the Fisher's exact test results (i.e., the higher the $p$-value, the greater the degree of agreement) except on specific roles and by elevation (Table 4). Among the productive roles for which there was a clear disagreement between men and women as identified by the Fisher exact test results (i.e. the smaller the $p$-value, the more consistent the degree of disagreement) that are specific to the upland areas are farm finances, maintaining farm records, selling agroforestry products and watering/irrigation. In the lowlands there was clear disagreement on gender roles with regard to selling agroforestry products and selling crops. Nevertheless, the results suggest that the majority of women perceive men are responsible for many of the agricultural activities. Women in the lowlands are becoming more involved in rubber tapping than the women in the uplands.

FIGURE 5 Distribution of gender specific productive roles (\%) along an elevation gradient, in $2013(N=202)$

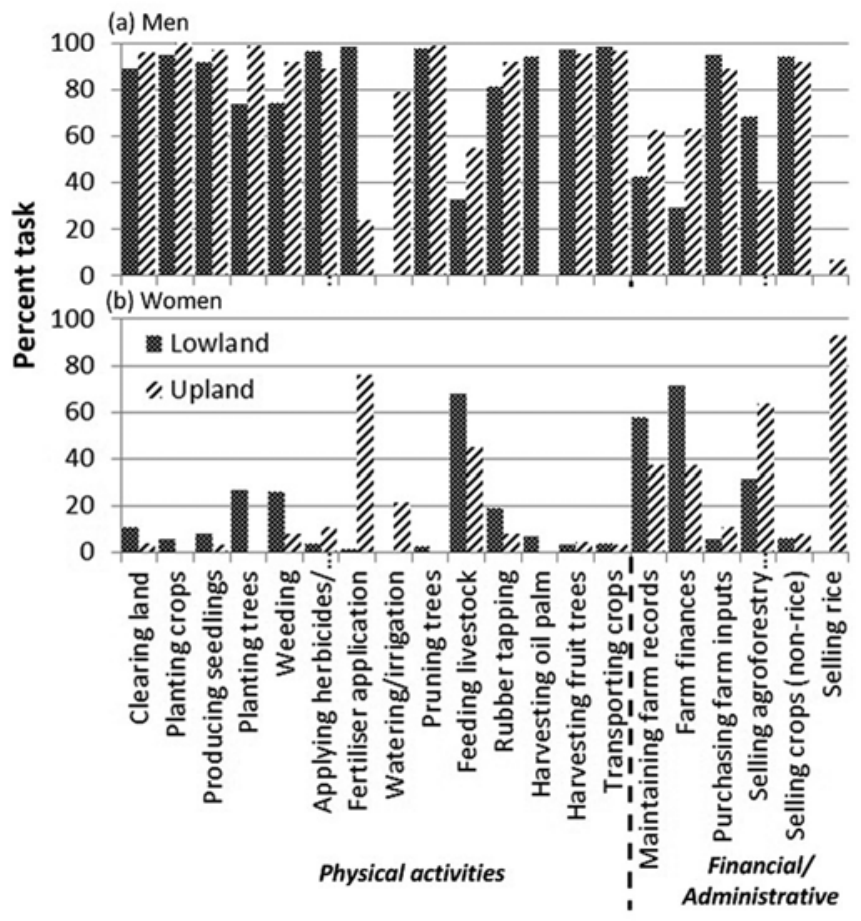


TABLE 4 Perspectives of men and women regarding 'who performs specific productive roles' in the Jambi Province, Sumatra in $2013(N=202)$

\begin{tabular}{|c|c|c|c|c|c|c|}
\hline \multirow{2}{*}{ Activity } & \multirow{2}{*}{ Elevation } & \multicolumn{2}{|c|}{ Men said... (\%) } & \multicolumn{2}{|c|}{ Women said... (\%) } & \multirow{2}{*}{$\begin{array}{c}\text { Fisher's exact tes } \\
(p)\end{array}$} \\
\hline & & "Men" & "Women" & "Men" & "Women" & \\
\hline \multirow[t]{2}{*}{ Applying herbicides/pesticides } & Lowland & 100 & 0 & 93 & 8 & 0.180 \\
\hline & Upland & 90 & 10 & 88 & 12 & 0.516 \\
\hline \multirow[t]{2}{*}{ Clearing land } & Lowland & 90 & 10 & 88 & 12 & 0.516 \\
\hline & Upland & 100 & 0 & 92 & 8 & 0.147 \\
\hline \multirow[t]{2}{*}{ Farm finances } & Lowland & 34 & 66 & 24 & 76 & 0.218 \\
\hline & Upland & 49 & 51 & 77 & 23 & 0.009 \\
\hline \multirow[t]{2}{*}{ Feeding livestock } & Lowland & 40 & 60 & 25 & 75 & 0.208 \\
\hline & Upland & 67 & 33 & 43 & 57 & 0.122 \\
\hline \multirow{2}{*}{ Fertiliser application } & Lowland & 100 & 0 & 97 & 3 & 0.654 \\
\hline & Upland & 29 & 71 & 19 & 81 & 0.238 \\
\hline \multirow{2}{*}{ Harvesting oil palm } & Lowland & 100 & 0 & 88 & 13 & 0.086 \\
\hline & Upland & 0 & 0 & 0 & 0 & - \\
\hline \multirow[t]{2}{*}{ Harvesting fruit trees } & Lowland & 100 & 0 & 94 & 6 & 0.281 \\
\hline & Upland & 96 & 4 & 95 & 5 & 0.702 \\
\hline \multirow[t]{2}{*}{ Transporting crops } & Lowland & 100 & 5 & 97 & 3 & 0.266 \\
\hline & Upland & 95 & 5 & 98 & 2 & 0.558 \\
\hline \multirow[t]{2}{*}{ Maintaining farm records } & Lowland & 50 & 50 & 35 & 65 & 0.154 \\
\hline & Upland & 50 & 50 & 75 & 25 & $\underline{0.017}$ \\
\hline \multirow[t]{2}{*}{ Planting crops } & Lowland & 95 & 5 & 94 & 6 & 0.730 \\
\hline & Upland & 100 & 0 & 100 & 0 & - \\
\hline \multirow[t]{2}{*}{ Planting trees } & Lowland & 74 & 26 & 73 & 27 & 0.603 \\
\hline & Upland & 100 & 0 & 98 & 2 & 0.558 \\
\hline \multirow[t]{2}{*}{ Producing seedlings } & Lowland & 94 & 6 & 90 & 10 & 0.479 \\
\hline & Upland & 98 & 3 & 96 & 4 & 0.553 \\
\hline \multirow[t]{2}{*}{ Pruning trees } & Lowland & 100 & 0 & 95 & 5 & 0.292 \\
\hline & Upland & 100 & 0 & 98 & 2 & 0.505 \\
\hline \multirow[t]{2}{*}{ Purchasing farm inputs } & Lowland & 95 & 5 & 94 & 6 & 0.601 \\
\hline & Upland & 89 & 11 & 89 & 11 & 0.601 \\
\hline \multirow[t]{2}{*}{ Selling agroforestry products } & Lowland & 83 & 17 & 54 & 46 & $\underline{0.012}$ \\
\hline & Upland & 23 & 77 & 50 & 50 & $\underline{0.019}$ \\
\hline \multirow[t]{2}{*}{ Selling crops (non-rice) } & Lowland & 100 & 0 & 88 & 12 & $\underline{0.029}$ \\
\hline & Upland & 93 & 7 & 91 & 9 & 0.526 \\
\hline \multirow[t]{2}{*}{ Selling rice } & Lowland & 0 & 0 & 0 & 0 & - \\
\hline & Upland & 7 & 93 & 7 & 93 & 0.639 \\
\hline \multirow[t]{2}{*}{ Rubber tapping } & Lowland & 94 & 6 & 68 & 32 & 0.055 \\
\hline & Upland & 92 & 8 & 92 & 8 & 0.680 \\
\hline \multirow[t]{2}{*}{ Watering/irrigation } & Lowland & 0 & 0 & 0 & 0 & - \\
\hline & Upland & 94 & 6 & 64 & 37 & $\underline{0.002}$ \\
\hline \multirow[t]{2}{*}{ Weeding } & Lowland & 71 & 29 & 77 & 23 & 0.494 \\
\hline & Upland & 94 & 6 & 90 & 10 & 0.468 \\
\hline
\end{tabular}

Note: Numbers in bold text represent significant results 
At the time of the survey the oil palm had not been harvested in the uplands because it had only recently been established. Rice fields are disappearing in the lowlands of the study area (Table 3). Productive roles such as watering/ irrigation and selling rice are low in the lowlands because they are associated with the upland rice farming system.

\section{Do men and women share similar perceptions about working together?}

To answer this question the same approach for testing the hypothesis, (H2) men and women have the same opinion about working together as working separately, was used. Out of the 20 productive roles identified, for three activities (i.e., fertiliser application in the lowlands, and planting crops and trees), it was found that men and women in the uplands have strong diverging opinions on working together (Table 5). About $50 \%$ of the men responded that applying fertiliser should be performed together, whereas among women only $19 \%$ perceived this work should be performed together with men (in the lowlands). Among women respondents in the uplands, 90\% regarded planting crops and $88 \%$ regarded planting trees as work that should be performed individually and especially by men (Table 5). We do not know if this is related to access to land rights or just to reduce the women's productive roles.

\section{DISCUSSION}

\section{How did gender-specific roles shift along land use changes?}

Our data shows that the hypothesis (H1) that 'Men and women have similar opinions about productive roles across the elevation gradient' should be rejected. From the analysis of land use/cover change of the study area, non-traditional monoculture rubber production has become the dominant land use, particularly in the lowlands. In fact, there is a growing amount of literature that documents the conversion of forests and rubber agroforest areas to monoculture rubber and oil palm plantations in Sumatra (Ekadinata et al. 2010, Koh and Ghazoul 2010, Ekadinata and Vincent 2011, Villamor et al. 2014a). In terms of farming practices, monoculture rubber differs considerably from rubber agroforestry systems because of the labour and farm inputs required. For example, the variability in the growth of cloned rubber trees (used in most of the monoculture rubber plantations) is highly dependent on management practices such as the frequency of weeding and pest control (Williams et al. 2001). The trend of increasing monoculture rubber production in the study area suggests that agriculture is shifting to more labour-intensive systems. If households rely exclusively on family labour, chances are high that women in those households would have more 'productive' responsibilities to perform. According to the survey results $32 \%$ of the lowland women reported that they are now involved in rubber tapping compared to $8 \%$ of upland women. Around $16 \%$ of the lowland women reported that they are now clearing land compared to $8 \%$ of the upland women. Fertiliser use is closely associated with monoculture rubber production and is considered a non-traditional agricultural practice. Lowland women are primarily responsible for applying fertiliser for monoculture rubber production whereas planting trees and planting crops remain the responsibility of men both in the lowlands and uplands (Table 4). In the lowlands, as rice field areas decrease monoculture rubber areas increase (Table 1). The weeding responsibilities of women in the rice fields have subsequently shifted to the monoculture rubber plantations. In contrast with the uplands, men are now working in the rice fields (i.e. harvesting), which was primarily performed by women under the traditional matrilineal inheritance system (Figure 1) (Colfer et al. 1988). Based on the in-depth interview results, rice field cultivation has become a shared or joint responsibility between husbands and wives. Nonetheless, the shift to more labour-intensive farming practices may increase the burden of responsibilities on women.

The role of women in small-scale oil palm cultivation is almost non-existent except for collecting fallen palm kernels (brondolan) during transport (reported by $13 \%$ of the lowland women respondents). According to the in-depth interview results, one of the main reasons for the gender bias in oil palm cultivation is that most of the harvesting activities are considered too strenuous for women, so families who have oil palm plantations limit the participation of women. However, the findings of Villamor et al. (2014c) in the land use role playing games showed that women in the lowlands expressed their

TABLE 5 Perspectives of men and women about 'joint productive roles' in Jambi Province, Sumatra in $2013(N=202)$

\begin{tabular}{llccccc}
\hline \multirow{2}{*}{ Activity } & \multirow{2}{*}{ Elevation } & \multicolumn{2}{c}{ Men said... (\%) } & \multicolumn{2}{c}{ Women said... (\%) } & Fisher's exact test \\
\cline { 3 - 6 } & & “Joint” & “Individual” & “Joint” & "Individual” & $(\boldsymbol{p})$ \\
\hline \multirow{2}{*}{ Fertiliser application } & Lowland & 49 & 51 & 19 & 81 & $\underline{\mathbf{0 . 0 0 2}}$ \\
\cline { 2 - 6 } & Upland & 60 & 40 & 50 & 50 & 0.379 \\
\hline \multirow{2}{*}{ Planting crops } & Lowland & 52 & 48 & 61 & 39 & 0.278 \\
\cline { 2 - 6 } & Upland & 30 & 70 & 10 & 90 & $\underline{\mathbf{0 . 0 1 3}}$ \\
\hline Planting trees & Lowland & 49 & 51 & 57 & 43 & 0.306 \\
\cline { 2 - 6 } & Upland & 32 & 68 & 12 & 88 & $\underline{\mathbf{0 . 0 1 8}}$ \\
\hline
\end{tabular}


land use preference for oil palm plantations and coal mining, which are mainly men's responsibilities. These observations suggest that women prefer land use types (e.g., oil palm plantation) that will reduce their productive roles and yet will contribute more to their household income due to the higher returns from these land uses. This partially contrasts with the evidence that smallholder oil palm expansion has targeted former rice fields. However, for landless households, women engaged as wage labourers in large-scale oil palm plantations are typically responsible for weeding, applying fertiliser, and preparing seedlings for lower wages than men who do the harvesting and pruning, which is consistent with the study of Julia and White (2012) in West Kalimantan.

Traditional rubber agroforestry systems remain one of the main livelihood sources in the study area. With regard to who should be responsible for selling agroforestry products, there is a strong divergence of opinion about it between men and women at both elevations (Figure 5). Lowland men said it is mainly their responsibility, which more than half of the women disagreed with. In contrast to the uplands, lowland men perceived greater participation of women in the selling of agroforestry crops. As noted by Villamor et al. (2014c), rubber agroforests are local sources of fruit and medicines, approximately on a par with the historical role of natural forests. Since natural lowland forests have already disappeared, this suggests that lowland women perceived rubber agroforests as being good value for meeting immediate household needs.

\section{Implications for gender equality and equity}

According to Quisumbing et al. (2001) gender equity and land use efficiency are mirrored in the division of labour and inheritance systems of central Sumatra. Male dominated rubber agroforestry systems are passed from fathers to their sons while women who are responsible for rice fields will pass them to their daughters. Our study focused only on the gender division of labour associated with the shift from traditional to non-traditional agricultural systems. To illuminate the matrilineal inheritance system in the study area data from an earlier study conducted by Villamor et al. (2014c) was used. Consequently, these data only represent the women's perspective. A more comprehensive resampling of the study summarized by Quisumbing et al. (2001) is in progress. Our current results show that lowland women have more equitable access to the inheritance of land used for monoculture rubber production, of which $76 \%$ was distributed equally among both sons and daughters, while upland women still strongly adhere to the traditional matrilineal inheritance system for rice fields only (Table 4). Because rice farming is no longer practiced by women respondents in the lowlands and rubber agroforestry systems are men's responsibility, inheritance practices for these systems could not be determined. To the contrary, more than $80 \%$ of the women respondents reported that rice fields would be inherited by their daughters and $50 \%$ reported the same for rubber agroforests (Figure 6). Combining these findings with our findings on genderspecific productive roles indicates that lowland women treat sons and daughters more equally relative to those in the uplands, who tend to favour daughters in land inheritance for rice fields. What this implies for conversion of rice fields to oil palm is not clear and may require follow-up discussions.

Further analysis of the space-time dimensions of this change in inheritance patterns alongside further integration in global commodity markets may make use of the multiple intersecting gradients: 1) the social gradient from core Minangkabau ethnic domain to Jambi ethnic groups with strong to weaker expression of matrilineal traditions, 2) gradients in (road) accessibility and associated degree of integrating migrants into local communities and/or de novo social structures in transmigration settlements, 3) terrain with differential suitability for the conversion of rubber to oil palm. This research may help clarify to what extent socially constructed gender is a 'context' (essentially exogenous variable, not open to change), or an 'option' (open to endogenous change). Normative external interpretations of equity are less relevant in this respect than local perceptions and agency for change.

While it is clear that gender roles are shifting as land use changes, women keep engaging in productive activities among new farming practices or land uses. This may over-burden

FIGURE 6 Women's perspectives regarding the transfer of land rights to their children across elevations in Jambi Province, Sumatra $(N=200)$

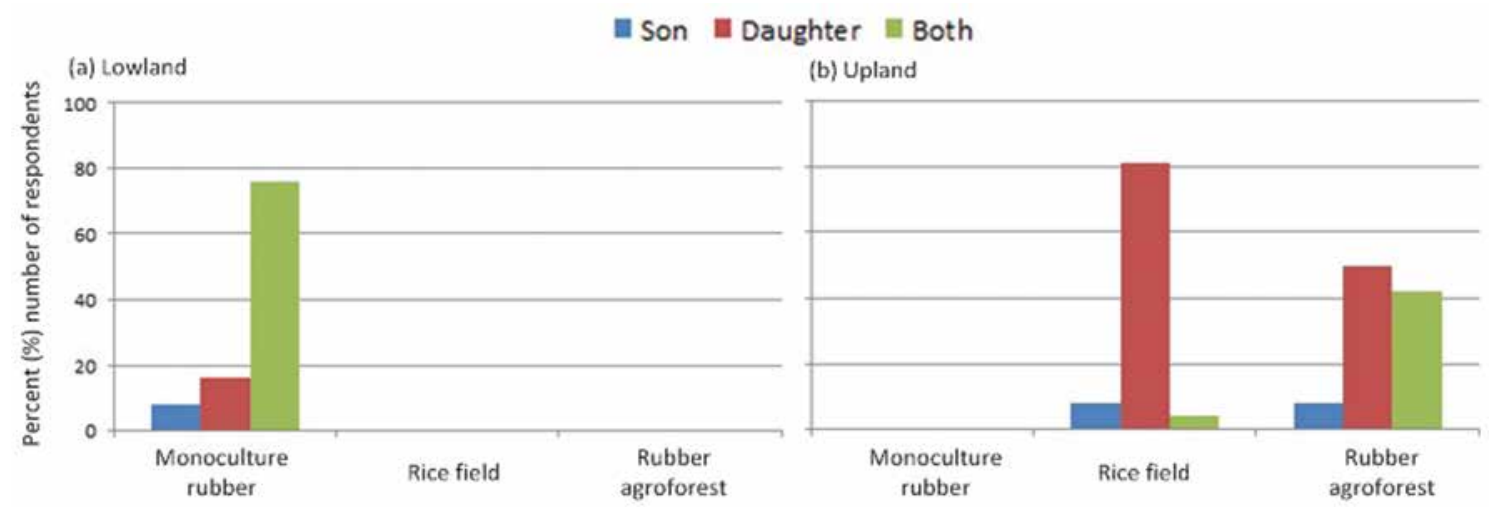


some women whose roles are already too demanding. However, women's choices may be determined by their particular circumstances, either by existing social norms, site-specific context, or due to other external factors (Villamor et al. 2015). In the Minangkabau case, the tendency of women to participate in productive activities in new land uses (e.g., oil palm plantation) is attributed to their matrilineal practices, which form the basis of social, land and labour. According to the in-depth studies of Minangkabau women by Blackwood (2008: 17), "the women-in-development literature tends to represent these women farmers as poor, down-trodden, and in need of liberation from their wearying toil." However, "this farm work is not carried out solely by individual women farmers and their families; instead, they rely on additional labour beyond their own households during critical phases of agricultural cycles". In the uplands, from our in-depth interviews, groups of women work in each other's rice fields during the growing season without being paid. In fact, there is this intersection of kin and labour relations creating cooperative labour networks, which Blackwood (2008) explained was based on ties of kinship and friendship and hence not limited solely to household availability of labour and perceptions of gender roles within it. Unfortunately, during our study, we were not able to assess the possible networks of women in rubber agroforests in the lowlands. Because these trends - the reduction in area devoted to rice fields in lowland areas, the proliferation of male-dominated farming practices, and the creation of new work-related networks by women in rubber production - may have offsetting effects, the net impact on gender equality is ambiguous and deserves further study.

\section{CONCLUSIONS}

This study provides new insights into how gender-specific roles shift in a landscape that is experiencing rapid land use transition. A simple approach was used to establish a baseline of gender-specific productive (as well as reproductive and community) roles in a particular landscape, and to assess whether there have been shifts in their specific gender roles as perceived by both men and women. This approach can be used to better understand the different and changing roles of men and women within a traditionally matrilineal society, in terms of responsibilities, potential benefits, and changing dynamics at the landscape level and provide a basis for monitoring trends in the future.

The results suggest that women in the lowlands (where the land use changes have been greatest) reported increasing participation in productive roles that were perceived by women in the uplands as men's responsibilities. Lowland women are now more involved in rubber tapping, planting rubber trees, and feeding livestock due to the shifts from traditional to non-traditional farming systems. Overall, women play a relatively greater role in controlling the financial side of the farm than doing the physical work.

Moreover, this study opens up new research questions on how to measure changes in gender relations in areas where there are strong social norms affecting the gender relations in terms of managing natural resources. Changes in infrastructure, prices and incentives, local governance and the expanding political space for local actions, have all had some influence on decision making within the households and their changing aspirations. Despite these changes, gender roles continue to change and affect power relations within the household. Can these changes in gender roles be used as a measure for gender equality or equity?

\section{ACKNOWLEDGEMENTS}

We appreciate the financial support of the "Forests, Trees, and Agroforestry" Research Program of the CGIAR. We thank Arif Prasetyo, Adis Hendriatna, Thoha Zulkarnain, Elissa Dwiyanti, Atiek Widayati and Sonya Dewi for access to and processing of the land use maps, Delia Catacutan, Carol Colfer, Utkur Djanibekov and Guido Lüchters for their suggestions and comments on an earlier draft, and four anonymous reviewers for their valuable comments and suggestions.

\section{REFERENCES}

ADESINA, A.A. and DJATO, K.K. 1997. Relative efficiency of women as farm managers: Profit function analysis in Côte d'Ivoire. Agricultural economics 16(1): 47-53.

AGRESTI, A. 1992. A survey of exact inference for contingency tables. Statistical Science 7(1): 131-153.

AKIEFNAWATI, R., VILLAMOR, G.B., ZULFIKAR, F., BUDISETIAWAN, I., MULYOUTAMI, E., AYAT, A. and VAN NOORDWIJK, M. 2010. Stewardship agreement to reduce emissions from deforestation and degradation (REDD): Lubuk Beringin's hutan desa as the first village forest in Indonesia. International Forestry Review 12(4): 349-360.

ALDWAIK, S.Z. and PONTIUS, R.G. 2012. Intensity analysis to unify measurements of size and stationarity of land changes by interval, category, and transition. Landscape and Urban Planning 106(1): 103-114.

BERNARD, F., VAN NOORDWIJK, M., LUEDELING, E., VILLAMOR, G.B., SILESHI, G.W. and NAMIREMBE, S. 2014. Social actors and unsustainability of agriculture. Current Opinion in Environmental Sustainability 6: 155-161.

BLACKWOOD, E. 1999. Big houses and small houses: Doing matriliny in West Sumatra. Ethnos 64(1): 32-56.

BLACKWOOD, E. 2008. Not your average housewife: Minangkabau women rice farmers in West Sumatra. Women and Work in Indonesia. 17-40 p. M. Ford and L. Parker. Oxon, Taylor \& Francis.

BROICH, M., HANSEN, M.C., POTAPOV, P., ADUSEI, B., LINDQUIST, E. and STEHMAN, S.V. 2011. Time-series analysis of multi-resolution optical imagery for quantifying forest cover loss in Sumatra and Kalimantan, Indone- 
sia. International Journal of Applied Earth Observation and Geoinformation 13(2): 277-291.

COLFER, C.J.P., GILL, D.W. and AGUS, F. 1988. An indigenous agricultural model from West Sumatra: a source of scientific insight. Agricultural Systems 26(3): 191-209.

COLFER, C.J.P. and MINARCHEK, R.D. 2013. Introducing 'The Gender Box': a framework for analysing gender roles in forest management 1. International Forestry Review 15(4): 411-426.

DEFRIES, R.S., RUDEL, T., URIARTE, M. and HANSEN, M. 2010. Deforestation driven by urban population growth and agricultural trade in the twenty-first century. Nature Geoscience 3(3): 178-181.

EKADINATA, E., THOHA ZULKARNAIN, M. and WIDAYATI, A. 2010. Agroforestry area under threats: dynamics and trajectories of rubber agroforest in Bungo District, Jambi. In: LEIMONA, B. and JOSHI, L. (eds.) Eco-certified natural rubber from sustainable rubber agroforestry in Sumatra, Indonesia. Bogor: World Agroforestry Centre.

EKADINATA, E. and VINCENT, G. 2011. Rubber agroforests in a changing landscape: analysis of land use/ cover trajectories in Bungo district, Indonesia. Forest, Trees and Livelihoods 20: 3-14.

ELMHIRST, R. 1999. Space, identity politics and resource control in Indonesia's transmigration programme. Political Geography 18(7): 813-835.

FEINTRENIE, L., SCHWARZE, S. and LEVANG, P. 2010. Are local people conservationists? Analysis of transition dynamics from agroforests to monoculture plantations in Indonesia. Ecology and Society 15(4): 37.

FISHER, R.A. 1922. On the interpretation of $\chi^{2}$ from contingency tables, and the calculation of P. Journal of the Royal Statistical Society 85(10): 87-94.

GALUDRA, G., VAN NOORDWIJK, M., AGUNG, P., SUYANTO, S. and PRADHAN, U. 2014. Migrants, land markets and carbon emissions in Jambi, Indonesia: Land tenure change and the prospect of emission reduction. Mitigation and Adaptation Strategies for Global Change 19(6): 715-731.

GATTO, M., WOLLNI, M. and QAIM, M. 2014. Oil palm boom and land-use dynamics in Indonesia - the role of policies and socioeconomic factors. EFForTS discussion paper series. Universität Göttingen GOEDOCDokumenten-und Publikationsserver der Georg-August-Universität Göttingen.

HARRIS, J. 2014. Gender implications of poor nutrition and health in agricultural households. In: QUISUMBING, A.R., MEINZEN-DICK, R., RANEY, T.L. et al. (eds) Gender in Agriculture. 267-283 Amsterdam: Springer Netherlands.

JELSMA, I., GILLER, K. and FAIRHURST, T. 2009. Smallholder oil palm production systems in Indonesia: lessons from the NESP Ophir project. Wageningen: Wageningen University.

JULIA and WHITE, B. 2012. Gendered experiences of dispossession: oil palm expansion in a Dayak Hibun community in West Kalimantan. Journal of Peasant Studies 39(3-4): 995-1016.
KATO, T. 1978. Change and continuity in the Minangkabau matrilineal system Indonesia, Southeast Asia Program Publications at Cornell University. 9: 10-16.

KOH, L.P. and GHAZOUL, J. 2010. Spatially explicit scenario analysis for reconciling agricultural expansion, forest protection, and carbon sequestration in Indonesia. Proceedings of the National Academy of Sciences 107(24): 11140-11144.

LAUMONIER, Y., URYU, Y., MICHAEL, S. and BUDIMAN, A. 2010. Eco-floristic sectors and deforestation threats in Sumatra: identifying new conservation area network prioirities for ecosystem-based land use planning. Biodiversity Conservation 19(4): 1153-1174.

LEE, J.S.H., ABOOD, S., GHAZOUL, J., BARUS, B., OBIDZINSKI, K. and KOH, L.P. 2014. Environmental impacts of large-scale oil palm enterprises exceed that of smallholdings in Indonesia. Conservation Letters 7(1): 25-33.

MARGONO, B.A., TURUBANOVA, S., ZHURAVLEVA, I., POTAPOV, P., TYUKAVINA, A., BACCINI, A., GOETZ, S. and HANSEN, M.C. 2012. Mapping and monitoring deforestation and forest degradation in Sumatra (Indonesia) using Landsat time series data sets from 1990 to 2010. Environmental Research Letters 7(3): 034010.

MARJANI, R. and IRAWATI, S. 1997. Economic analysis of land use system for large scale plantations of oil palm and industrial timber estate. Southeast Asia Policy Research Bogor, Alternative Slash and Burn (ASB). Working Paper 2.

MEINZEN-DICK, R.S., BEHRMAN, J., MENON, P. and QUISUMBING, A. 2012. Gender: a key dimension linking agricultural programs to improved nutrition and health. In: SHENGGEN FAN and PANDYA-LORCH, R. (eds.) Reshaping Agriculture for Nutrition and Health. 135-144. Washington, DC: International Food Policy Research Institute.

MEINZEN-DICK, R.S., BROWN, L.R., FELDSTEIN, H.S. and QUISUMBING, A.R. 1997. Gender, property rights, and natural resources. World development 25(8): 13031315.

MEINZEN-DICK, R.S., KOVARIK, C. and QUISUMBING, A. 2014. Gender and sustainability. Annual Review of Environment and Resources 39(1): 29-55.

MIYAMOTO, M. 2006. Forest conversion to rubber around Sumatran villages in Indonesia: comparing the impacts of road construction, transmigration projects and population. Forest Policy and Economics 9: 1-12.

MULYOTAMI, E., CATACUTAN, D., MARTINI, E., KHUSUSIYAH, N., JANUDIANTO, VILLAMOR, G.B. and VAN NOORDWIJK, M. 2013. Gender roles in land use and value chains (GRoLUV). Negotiation-support toolkit for learning landscapes. In: VAN NOORDWIJK, M., LUISIANA, B., BERIA, L., DEWI, D. AND WULANDARI, D. (eds). 55-60. Negotiation-Support Toolkit for Learning Landscapes. Bogor: World Agroforestry Center (ICRAF).

OTSUKA, K., SUYANTO, S., SONOBE, T. and TOMICH, T.P. 2001. Evolution of land tenure institutions and development of agroforestry: evidence from customary land areas of Sumatra. Agricultural Economics 25(1): 85-101. 
PETER, G. 2006. Gender roles and relationships: implications for water management. Physics and Chemistry of the Earth, Parts A/B/C 31(15-16): 723-730.

QUISUMBING, M.A.R. and OTSUKA, K. 2001. Land inheritance and schooling in matrilineal societies: evidence from Sumatra. World Development 29(12): 2093-2110.

QUISUMBING, M.A.R., OTSUKA, K., SUYANTO, AIDOO, J. and PAYONGAYONG, E. 2001. Land, trees, and women: evolution of land tenure institutions in Western Ghana and Sumatra. IFPRI Research Report 121. Washington, DC, International Food Policy Research Institute. 121.

RAZAVI, S. and MILLER, C. 1995. From WID to GAD: conceptual shifts in the women and development discourse. Geneva, United Nations Research Institute for Social Development Working Paper No. 1.

RIST, L., FEINTRENIE, L. and LEVANG, P. 2010. The livelihood impacts of oil palm: smallholders in Indonesia. Biodiversity and Conservation 19(4): 1009-1024.

RUDEL, T.K., DEFRIES, R., ASNER, G.P. and LAURANCE, W.F. 2009. Changing drivers of deforestation and new opportunities for conservation. Conservation Biology 23(6): 1396-1405.

SUYANTO, S., TOMICH, T.P. and OTSUKA, K. 2001. Land tenure and farm management efficiency: the case of smallholder rubber production in customary land areas of Sumatra. Agroforestry Systems 52: 145-160.

UDRY, C., HODDINOTT, J., ALDERMAN, H. and HADDAD, L. 1995. Gender differentials in farm productivity: implications for household efficiency and agricultural policy. Food policy 20(5): 407-423.

VAN NOORDWIJK, M., MURDIYARSO, D., HAIRIAH, K., WASRIN, U., RACHMAN, A. and TOMICH, T. 1998. Forest soils under alternatives to slash-and-burn agriculture in Sumatra, Indonesia. In: SCHULTE, A. and RUHIYAT, D. (eds.) Soils of Tropical Forest Ecosystems. 175-185. Heidelberg: Springer Berlin.

VAN NOORDWIJK, M., TATA, H.L., XU, J., DEWI, S. and MINANG, P.A. 2012. Segregate or integrate for multifunctionality and sustained change through rubber-based agroforestry in Indonesia and China: agroforestry. In: NAIR, P.K.R. AND GARRITY, D. The Future of Global Land Use. Advances in Agroforestry 9. 69-04 Amsterdam: Springer Netherlands.

VILLAMOR, G.B., DAH-GBETO, A., BELL, A., PRADHAN, U. and VAN NOORDWIJK, M. 2015. Genderspecific spatial perspectives and scenario building approaches for understanding gender equity and sustainability in climate smart landscapes. In: MINANG, P., VAN NOORDWIJK, M., FREEMAN, O. et al. (eds). Climate-Smart landscapes: Multifunctionality $t$ Practice. Nairobi: World Agroforestry Centre (ICRAF).

VILLAMOR, G.B., PONTIUS, R.G., JR. and VAN NOORDWIJK, M. 2014a. Agroforest's growing role in reducing carbon losses from Jambi (Sumatra), Indonesia. Regional Environmental Change 14(2): 825-834.

VILLAMOR, G.B., VAN NOORDWIJK, M., DJANIBEKOV, U., CHIONG-JAVIER, M. and CATACUTAN, D. 2014b. Gender differences in land-use decisions: shaping multifunctional landscapes? Current Opinion in Environmental Sustainability 6: 128-133.

VILLAMOR, G.B., DESRIANTI, F., AKIEFNAWATI, R., AMARUZAMAN, S. and VAN NOORDWIJK, M. 2014c. Gender influences decisions to change land use practices in the tropical forest margins of Jambi, Indonesia. Mitigation and Adaptation Strategies for Global Change 19(6): 733-755.

WIBAWA, G., HENDRATNO, S. and VAN NOORDWIJK, M. 2005. Permanent smallholder rubber agroforestry systems in Sumatra, Indonesia. p. In: PALM, C., VOSTI, S.A., SANCHEZ, P.A., and ERICKSEN, P.J. (eds). Slash-and-Burn Agriculture: The Search for Alternatives. 222-231. New York: Columbia University Press.

WILLIAMS, S.E., VAN NOORDWIJK, M., PENOT, E., HEALEY, J.R., SINCLAIR, F.L. and WIBAWA, G. 2001. On-farm evalution of the establishment of clonal rubber in multi-strata agroforests in Jambi, Indonesia. Agroforestry Systems 53: 227-237. 
APPENDIX 1 Transitional intensity level analysis equations and mathematical notations based on Villamor et al. (2014a).

The transition level examines how the size of transitions during an interval vary with respect to the size of the categories available for those transitions. Table A1 gives the notation used in the equations. Equation 1 computes the uniform transition intensity for the gain of category $n$ from all non- $n$ categories during $\left[Y_{t}, Y_{t+1}\right]$ while Equation 2 computes the observed intensity of the transition from $i$ to $n$ during $\left[Y_{t}, Y_{t+1}\right]$.

Table A1 Mathematical notation

\begin{tabular}{|c|c|}
\hline$T$ & Number of time points, which equals 3 for our case study \\
\hline$Y_{t}$ & Year at time point $t$ \\
\hline$t$ & Index for the initial time point of interval $\left[Y_{t}, Y_{t+1}\right]$, where $t$ ranges from 1 to $T-1$ \\
\hline$J$ & Number of categories \\
\hline$i$ & Index for a category at an interval's initial time point \\
\hline$j$ & Index for a category at an interval's final time point \\
\hline$m$ & Index for the losing category for the selected transition \\
\hline$n$ & Index for the gaining category for the selected transition \\
\hline$C_{t i j}$ & Number of pixels that transition from category $i$ to category $j$ during interval $\left[Y_{t}, Y_{t+1}\right]$ \\
\hline$R_{\text {tin }}$ & $\begin{array}{l}\text { Intensity of annual transition from category } i \text { to category n during interval }\left[Y_{t}, Y_{t+1}\right] \text { relative to size of category } i \text { at time } t \\
\text { where } i=n\end{array}$ \\
\hline$W_{t n}$ & $\begin{array}{l}\text { Uniform intensity of annual transition from all non- } n \text { categories to category } n \text { during interval }\left[Y_{t}, Y_{t+1}\right] \text { relative to size of } \\
\text { all non- } n \text { categories at time } t\end{array}$ \\
\hline$Q_{t m j}$ & $\begin{array}{l}\text { Intensity of annual transition from category } \mathrm{m} \text { to category } \mathrm{j} \text { during interval }\left[Y_{t}, Y_{t+1}\right] \text { relative to size of category } j \text { at time } \\
t+1 \text { where } j=m\end{array}$ \\
\hline$V_{t m}$ & $\begin{array}{l}\text { Uniform intensity of annual transition from all non- } m \text { categories to category } j \text { during interval }\left[Y_{t}, Y_{t+1}\right] \text { relative to size of } \\
\text { all non- } m \text { categories at time } t+1\end{array}$ \\
\hline
\end{tabular}

$$
\begin{gathered}
W_{t n}=\frac{\left(\text { area of gain to } n \text { during }\left[Y_{t}, Y_{t+1}\right]\right) 100 \%}{\left(\text { duration of }\left[Y_{t}, Y_{t+1}\right]\right) \text { area of non }-n \text { at } Y_{t}}=\frac{\left[\left(\sum_{i=1}^{J} C_{t i n}\right)-C_{t n n}\right] 100 \%}{\left(Y_{t+1}-Y_{t}\right) \sum_{i=1}^{J} C_{t i j}\left[\left(\sum_{i=1}^{J} C_{t i j}\right)-C_{t n j}\right]} \\
R_{t i n}=\frac{\left(\text { area of transition from } i \text { to } n \text { during }\left[Y_{t}, Y_{t+1}\right]\right) 100 \%}{\left(\text { duration of }\left[Y_{t}, Y_{t+1}\right]\right) \text { area of } i \text { at } Y_{t}}=\frac{C_{t i n} 100 \%}{\left(\left[Y_{t}, Y_{t+1}\right] \sum_{j=1}^{J} C_{t i j}\right)}
\end{gathered}
$$

Equation 3 computes the uniform transition intensity for the loss of category $m$ from all non- $m$ categories during $\left[Y_{t}, Y_{t+1}\right]$ while Equation 4 computes the observed intensity of the transition from $m$ to $j$ during $\left[Y_{t}, Y_{t+1}\right]$.

$$
\begin{gathered}
V_{t m}=\frac{\left(\text { area of loss from } m \text { during }\left[Y_{t}, Y_{t+1}\right]\right) 100 \%}{\left(\text { duration of }\left[Y_{t}, Y_{t+1}\right]\right) \text { area of non }-m \text { at } Y_{t+1}}=\frac{\left[\left(\sum_{j=1}^{J} C_{t m j}\right)-C_{t m m}\right] 100 \%}{\left(Y_{t+1}-Y_{t}\right) \sum_{i=1}^{J} C_{t i j}\left[\left(\sum_{j=1}^{J} C_{t i j}\right)-C_{t i m}\right]} \\
Q_{t m j}=\frac{\left(\text { area of transition from } m \text { to } j \text { during }\left[Y_{t,} Y_{t+1}\right]\right) 100 \%}{\left(\text { duration of }\left[Y_{t}, Y_{t+1}\right]\right) \text { area of } j \text { at } Y_{t+1}}=\frac{C_{t m j} 100 \%}{\left(\left[Y_{t,} Y_{t+1}\right] \sum_{j=1}^{J} C_{t i j}\right)}
\end{gathered}
$$

